Vol. 44, N. 3 : pp. $269-276$, September, 2001

ISSN 1516-8913 Printed in Brazil

\title{
Spatial and Temporal Variation in the Canopy Cover in a Tropical Semi-Deciduous Forest
}

\author{
Edmilson Bianchini ${ }^{1 *}$, José A. Pimenta ${ }^{1}$ and Flavio A. M. dos Santos ${ }^{2}$ \\ ${ }^{I}$ Departamento de Biologia Animal e Vegetal, CCB, Universidade Estadual de Londrina, Caixa Postal 6001, \\ Londrina, PR. 86051-970. ${ }^{2}$ Departamento de Botânica, IB, UNICAMP, Caixa Postal 6109, Campinas, SP. 13083- \\ 970
}

\begin{abstract}
This study was developed in the Mata dos Godoy State Park $\left(23^{\circ} 27^{\prime} \mathrm{S}, 51^{\circ} 15^{\prime} \mathrm{W}\right)$ South Brazil which present great environmental heterogeneity when its north portion (ridge) is compared with the southern portion (valley), where there are some flooded areas. The forest formation is classified as tropical semi-deciduous forest. Spatial and temporal variations in the degree of the canopy cover were compared at flooded and unflooded sites. The measures were taken seasonally in $100 \mathrm{~m}^{2}$ plots using a spherical densiometer from spring 1995 to winter 1996. The flooded area was more open and lighter and had a greater spatial and temporal variation in the canopy cover than the unflooded areas. The greater heterogeneity in the flooded area could be due to structural characteristics of the canopy (greater spacing between individual trees, lower canopy and less stratified canopy), more frequent natural disturbances and a greater degree of deciduousness. These causes seemed to be related to the presence of the river and flooding.
\end{abstract}

Key words: Canopy, flooding, seasonality, spatial heterogeneity, tropical forest

\section{INTRODUCTION}

There is great variation in micro-environmental factors in the understoreys, such as light availability. In a study developed in tropical rain forest of Costa Rica, Nicotra et al. (1999) observed great spatial heterogeneity of light in the understorey. This spatial heterogeneity of light can be related gaps, the structural complexity and/or deciduousness of the canopy.

Tropical forests can be considered a mosaic of vegetation patches at different successional stages (Martínez-Ramos et al., 1989). This spatial and temporal variation in the forest structure results from falling branches and trees, which form gaps in the canopy and create heterogeneity in the environment (Denslow, 1980; Martínez-Ramos, 1985).
The frequency of natural disturbance events in a forest varies among localities. The formation of large gaps produced by tree fall can be more abundant on river edges and in rocky sloping soils because of flooding, superficial root systems and wind (Gomez-Pompa \& Vázquez-Yanes, 1985). However, the spatial frequency of small gaps, produced by branch and twig fall, is much greater than that of large gaps (Martínez-Ramos, 1985).

Regardless of the disturbance event, the tropical forests have a heterogeneous canopy, because closed canopy is as heterogeneous as gaps (Lieberman et al., 1989). Within and among stands variation in forest canopy structure and foliage height distribution profoundly influences overall understorey light availability as well as its spatial distribution (Nicotra et al., 1999).

\footnotetext{
${ }^{*}$ Author for correspondence
} 
Although annual precipitation is high, many tropical forests have a dry period because of a seasonal decrease in rain (Richards, 1952). These forests are at least partially deciduous in this period, and their trees frequently have a major leaf flush at the beginning of the rainy season (Mulkey et al., 1996). The mean radiation of a meter above of soil in the understorey of a Mexican deciduous forest in the wet season was nine times smaller than in the dry season (Lerdau et al., 1992). Temporal variations in radiation may also occur in semi-deciduous forests, which may increase further their spatial heterogeneity. These temporal and spatial variations may influence species regeneration. The deciduousness of the canopy species may be one of the possible explanations for the occurrence of juveniles of pioneer species in the forest understorey (Hubbell \& Foster, 1987). However, little data is available in the literature on changes in the luminosity of the understorey in tropical deciduous (Bellingham et al., 1996) and semi-deciduous forests.

Luminosity variations also cause changes in temperature, nutrient availability and other environmental properties, which may influence the dynamic of tree populations under divergent spatial and temporal scales (Spies \& Franklin, 1989; Whitmore, 1989). Thus studies focusing on factors such as light and temperature are important to advance knowledge on forest structure and dynamic and for greater understanding of natural regeneration (Denslow \& Hartshorn, 1994).

Tropical semi-deciduous forest used to cover all the north of Paraná state, South Brazil have been intensely devastated and today only some remnants are left, and one of these is Mata dos Godoy State Park (Fig. 1). It contains great environmental heterogeneity when north portion (ridge) is compared with the southern portion (valley) where there are some flooded areas. Furthermore, this forest loses a great quantity of leaves during the winter, but it does not seem to be homogeneous for the whole park.

So, this study compares the degree of canopy covering in flooded and unflooded areas of the Park during the year to answer to the following questions:

1 - Does the degree of canopy cover vary among the flooded and unflooded areas in the Park?

2 - Does the flooded area show greater spatial and temporal heterogeneity in the canopy cover than the unflooded areas?

\section{MATERIAL AND METHODS}

\section{Study area}

The study was carried out at Mata dos Godoy State Park, Londrina (PR) which is cut by the Tropic of Capricorn (it has its headquarter center at $23^{\circ} 27^{\prime} \mathrm{S}$, $51^{\circ} 15^{\prime \prime} \mathrm{W}$ ) and consists of 680 ha in optimum preservation condition (Fig. 1). It is a smooth plain in the northern part, with some parallel hills with moderate slopes in the southern part. Some of these hill slopes reach the Apertados stream, which bounds the southern part of the Park, forming high edges, or end in an alluvial area approximately $10-30 \mathrm{~m}$ wide, which is subject to flooding. Annual rainfall averages c. 1,600 mm. The rainfall during the summer (December $=230$ $\mathrm{mm}$ ) is about twice that in the winter (August $=51$ $\mathrm{mm}$ ), characterizing two well-defined seasons. Annual average temperature is $21^{\circ} \mathrm{C}$. In the winter, the temperature goes down to about to $5^{\circ} \mathrm{C}$.

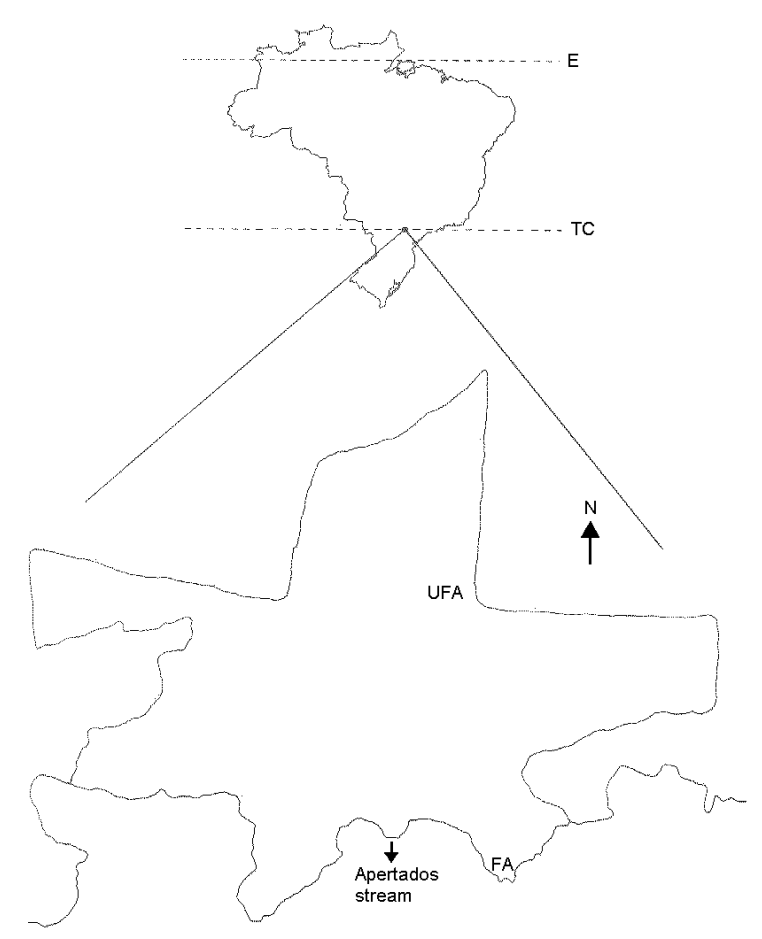

Figure 1 - The Mata dos Godoy State Park in South Brazil and an outline of the Park. FA - flooded area; UFA - unflooded area.

The forest is primary tropical semi-deciduous forest. The forest canopy height ranges between 10 $-20 \mathrm{~m}$ with emergence species that may reach 40 $\mathrm{m}$ such as Ficus glabra and Aspidosperma polyneuron. Leguminosae, Myrtaceae, 
Euphorbiaceae and Lauraceae are the main families of flowering plants of the Park.

\section{Canopy}

The degree of canopy cover was sampled in two areas in the Park, one subject to flooding and the other not. The flooded area (FA) at an altitude of approximately $500 \mathrm{~m}$, is localized on the edges of the Apertados stream on flat land and the unflooded area (UFA) is in the northern part of the Park (ridge) at approximately $600 \mathrm{~m}$ altitude, about $2 \mathrm{~km}$ from the stream.

In the FA 50 plots were established $(10 \mathrm{~m} \times 10 \mathrm{~m})$ totaling $5000 \mathrm{~m}^{2}(0.5 \mathrm{ha})$. As the flooded parts of the park were restricted and discontinuous, the plots were placed in three groups, two with 16 and one with 18 contiguous plots. A total of 100 plots $(10 \mathrm{~m} \times 10 \mathrm{~m})$, were established in the UFA, subdivided in two groups of 50 plots $(0.5 \mathrm{ha})$. The plots of first group (UFA1) were placed contiguously, forming a $50 \times 100 \mathrm{~m}$ rectangle. The plots of other group (UFA2) were distributed following the plot allocation scheme of FA. The allocation map of the plots can be observed in Bianchini (1998).

The cover index was measured simultaneously in the three sample areas in spring (October, 1995), summer (February, 1996), autumn (May, 1996) and winter (August, 1996) to compare the degree of cover among the seasons and to observe temporal variations among and within the sample areas. The three areas were analyzed separately and it was possible to discuss influences of plot distribution and differences in heterogeneity in canopy coverage between UFA areas and between UFA and FA. Four measurements of the cover index were obtained for each plot. The measurements were taken from the center of the plot in direction of a corner, considered as a quadrant. A total of 200 quadrants were measured for each sample area. The cover indices were obtained using a spherical densiometer (Lemmon, 1956) and measurements were taken at breast level (1.3 m).

\section{Data analysis}

The data was grouped in several ways. First, a mean canopy cover index was established for each quadrant considering the four measurements (four seasons). This mean canopy cover index for quadrants was then divided in three canopy cover classes: $>90 \%,>80 \%-90 \%$ and $<80 \%$. The $\chi^{2}$ value between the number of observed quadrants and number of expected quadrants for each cover class was calculated to investigate whether the canopy cover index of each quadrant differed significantly among sample areas. The number of expected quadrants was found by adding the results of three sample areas and calculating the average of quadrants in each canopy cover class.

Second, the canopy cover index for each season was compared using Box Plot. The Box Plots show median (horizontal bar), $25^{\text {th }}$ and $75^{\text {th }}$ percentiles (box), the 95\% confidence interval (notch), and minimum and maximum values (vertical bar). Data were transformed (arcsinsquare-root of proportion) before analysis.

Third, the relationship between the summer canopy cover index and the winter canopy cover index of winter was investigated using linear regression analysis. The $\%$ value were arcsinsquare-root-transformed before analysis. The relationship indicates whether variation was related only to deciduousness.

\section{RESULTS}

The flooded area had significantly less coverage and greater spatial variation than the unflooded areas (Fig. 2, Table 1). In FA, 47\% of the quadrants had cover indices greater than $90 \%$ while in UFA 1 and UFA2, $72.5 \%$ and $74.5 \%$ of the quadrants had cover indices greater than $90 \%$ (Fig. 2, Tab 1). The canopy coverage variation generally occurred on a small spatial scale within the plots (quadrants) especially in FA (Fig. 2).

When the seasons were compared, the flooded area of the Park had generally lower cover indices than the unflooded areas, especially in the winter when the differences were significant. The cover indices in the unflooded areas were similar (Fig. 3). The forest canopy was more open in the winter, confirming its semi-deciduous classification. The vegetation begins to leaves sprout (E. Bianchini, personal observation) from September onwards, with the increase in precipitation and the forest canopy becomes more closed in the springsummer (Fig. 3).

The majority of the quadrants had cover indices of over $90 \%$ in the spring, summer and autumn for the three sampled areas (Fig. 4A-C). However, a greater number of quadrants in the FA area had cover index $<90 \%$. In the winter, about $37 \%$ of the FA quadrants had cover index $<80 \%$ but the index was $>90 \%$ in only about $7 \%$ of them. In the unflooded areas, 9\% (UFA1) and 16\% (UFA2) of the quadrants has $<80 \%$ cover, while in about $35 \%$ 
of them the index was $>90 \%$ for both sample areas (Fig. 4D). The results indicate that the FA area has a more open forest canopy than the UFAs.
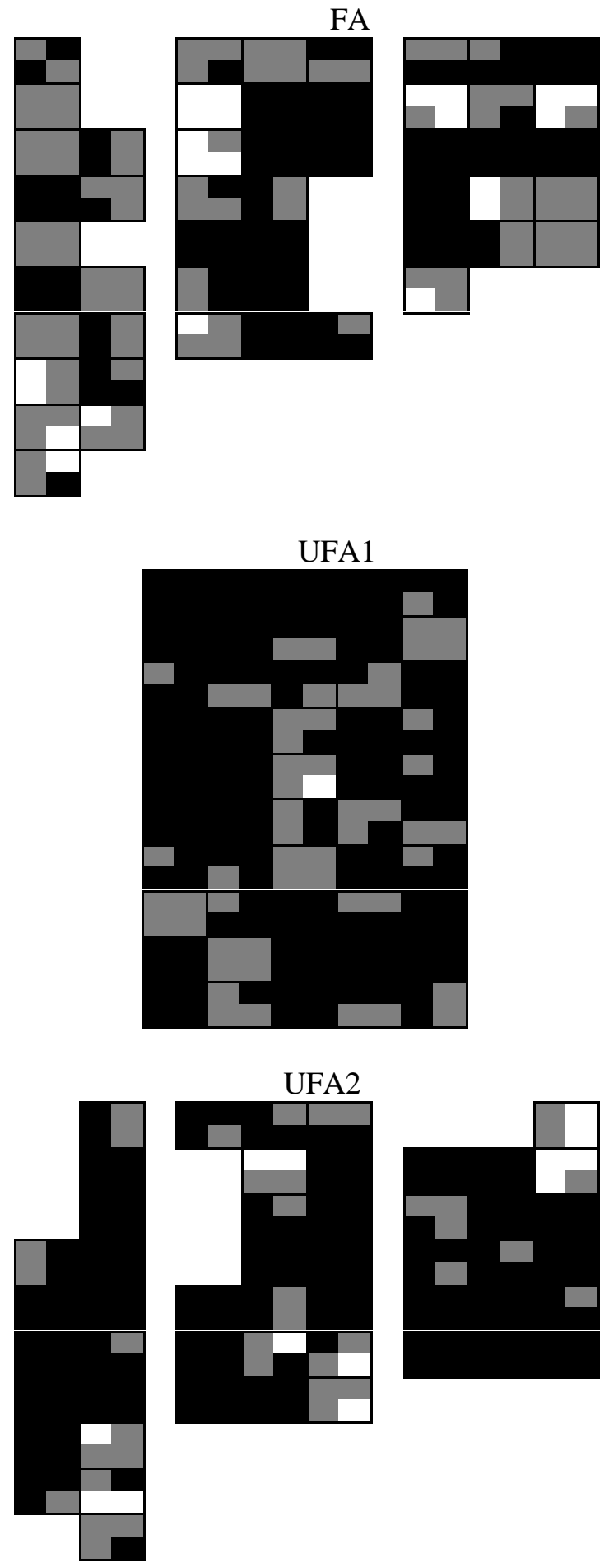

Figure 2 - Cover index (CI) of each quadrant in the plots $(10 \mathrm{~m} \times 10 \mathrm{~m})$ of the flooded (FA) and unflooded areas (UFA1 and UFA2) of the Mata dos Godoy State Park, Londrina, PR. The index is the mean of the measures in the four seasons. Black quadrants IC >
90\%; grey quadrants IC > 80-90\%; white quadrants IC $<80 \%$.

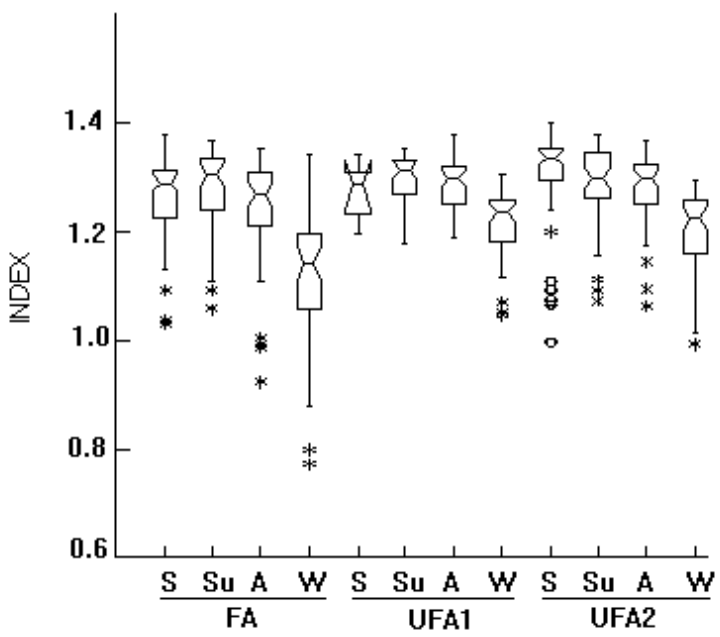

Figure 3 - Box plot of cover index (arcsin square root proportion) of canopy of the Mata dos Godoy State Park, Londrina, PR. S - spring; Su - summer; A autumn; W - winter. Flooded area (FA) and unflooded areas (UFA1 and UFA2). Boxes show median, the 95\% confidence interval and $25^{\text {th }}$ and $75^{\text {th }}$ percentiles. Bars indicate range distribution. ${ }^{*}$ and ${ }^{\circ}$ represent extreme and very extreme points, respectively.

Table $1-\chi^{2}$ analysis for number of observed quadrants and number of expected quadrants per canopy cover index class, in the Mata dos Godoy State Park, Londrina, PR. FA - flooded area; UFA - unflooded areas. * $\mathrm{p} \leq 0.05 ; \mathrm{Ns} \mathrm{p}>0.05$.

\begin{tabular}{|c|c|c|c|c|}
\hline areas & class & \multicolumn{2}{|c|}{ observed expected } & $\chi^{2}$ \\
\hline \multirow[t]{4}{*}{ FA } & $>90 \%$ & 94 & 129 & $9.22 *$ \\
\hline & $>80 \%-90 \%$ & 84 & 59 & $10.17 *$ \\
\hline & $<80 \%$ & 22 & 12 & $7.50 *$ \\
\hline & Total & 200 & & \\
\hline \multirow[t]{4}{*}{ UFA1 } & $>90 \%$ & 145 & 129 & 1.86 \\
\hline & $>80 \%-90 \%$ & 54 & 59 & 0.34 \\
\hline & $<80 \%$ & 1 & 12 & $9.20 *$ \\
\hline & Total & 200 & & \\
\hline \multirow[t]{4}{*}{ UFA2 } & $>90 \%$ & 149 & 129 & 2.95 \\
\hline & $>80 \%-90 \%$ & 38 & 59 & $7.12 *$ \\
\hline & $<80 \%$ & 13 & 12 & 0.02 \\
\hline & Total & 200 & & \\
\hline
\end{tabular}

The relationship among the cover indices in the summer and winter was positive and significant 
for the three sampled areas (Fig. 5), indicating that generally the quadrants with greater luminosity were the same in the summer and winter. However, the values of coverage were more dispersed in the flooded area than in the unflooded areas. In some quadrants, the cover index was higher in the summer and fairly low in winter, suggesting the presence of totally or partially deciduous trees at these points (Fig. 5 A-C). The dispersion of coverage values was similar between unflooded areas. This was in accordance with the greatest difference in the canopy coverage between summer and winter shown by the FA. The great dispersion of the points also showed the high heterogeneity in the degree of cover variation in the FA sites during the year.

\section{DISCUSSION}

The forest canopy can vary in species composition, height above to the soil, as well as in thickness and foliage density (Lieberman et al., 1989). The aggregation of crowns in the canopy depends on the spatial distribution of the individuals and the gap formation (Smith et al., 1989). Therefore, the spatial arrangement of the plants, their crown architecture and leaf area will determine the light penetration through the forest canopy, and several factors (such as flooding) can interfere in these canopy characteristics.

Flooding is related to the pluviometric system, local topography, soil type and river courses. The flooded area studied (FA) is located in a meander portion where the Apertados stream tends to modify its bed by erosion and sediment deposition. Thus several points in this region had different sediment deposition ages and consequently the vegetation in these places may be at different successional stages. The vegetation in the FA has different characteristics from the vegetation of the topographically higher areas. Therefore, the greater spatial and temporal heterogeneity of FA is due to its sporadic flooding.
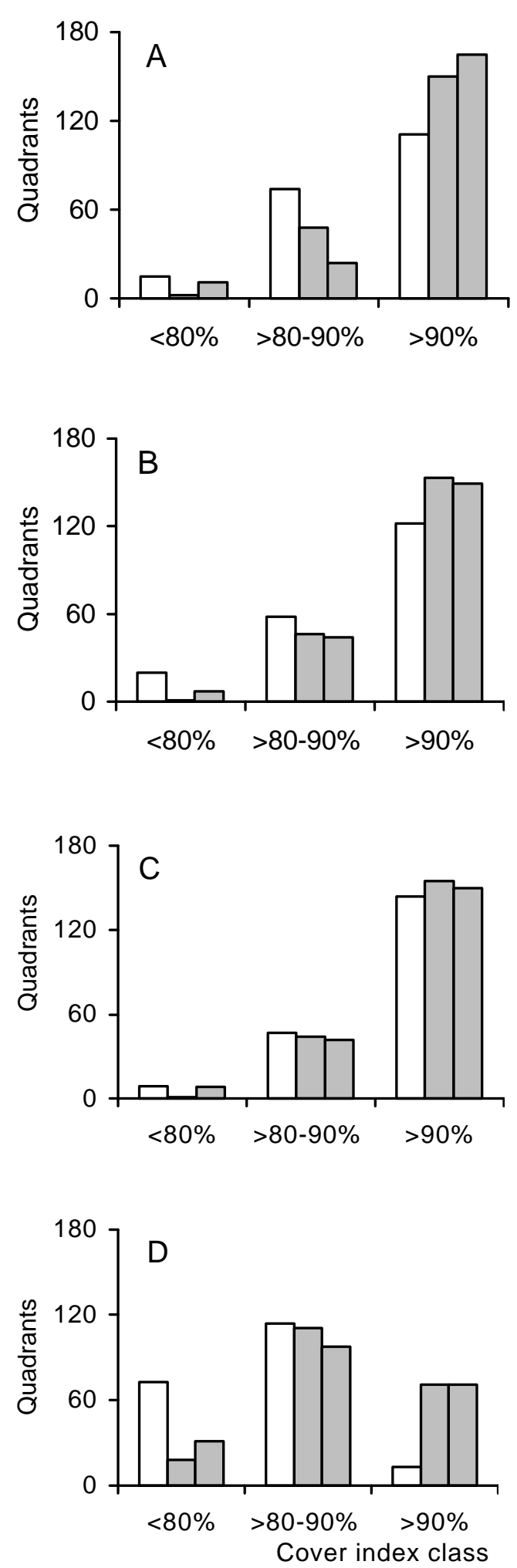

Figure 4 - Number of quadrants per canopy cover index class, in the Mata dos Godoy State Park, Londrina, PR. A - spring; B - summer; C - autumn; D - winter. 

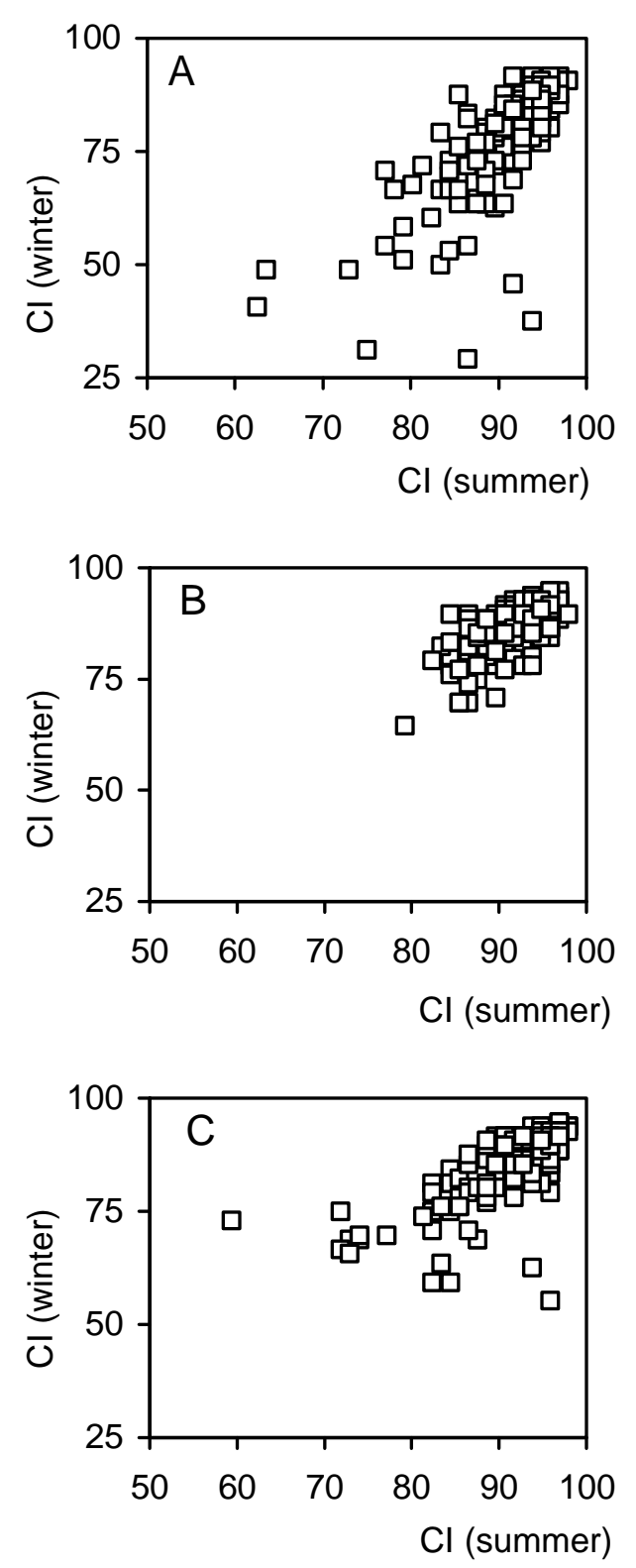

Figure 5 - Correlation of the canopy cover indices (CI) in the summer and winter for the three sampled areas in the Mata dos Godoy State Park, Londrina, PR. A flooded area $(\mathrm{r}=0.77 ; \mathrm{p}<0.001 ; \mathrm{n}=200)$; $\mathrm{B}$ - unflooded area $1(\mathrm{r}=0.67 ; \mathrm{p}<0.001 ; \mathrm{n}=200) ; \mathrm{C}-$ unflooded area 2 $(\mathrm{r}=0.71 ; \mathrm{p}<0.001 ; \mathrm{n}=200)$.

Plant diversity tends to be lesser in areas subject to flooding (Joly, 1991) and the flooding may influence the canopy tree composition (Mori \& Becker, 1991), and the establishment of a continuous tree cover (Denslow \& Hartshorn, 1994). Furthermore, the roots are more superficial in these areas and the soils are more unstable during flooding (Martínez-Ramos, 1985), which increases the chance of damage (falling, breaking or death) in the individuals and limits the height growth in others. Silveira (1993) observed marked difference in the Mata dos Godoy State Park in the species composition between the alluvial area at the edge of the Apertados stream and the forest area at the top of the slope. Only seven species were common to both areas, while 31 species were found only in the second area and 20 species only in the first area. Furthermore, the alluvial area canopy was more discontinuous than the area at the top of the slope canopy. No defined stratification was observed in the Park in the present study. However, the trees which make up the forest canopy in the FA area tend to be more spaced out, the majority with crowns between 8 and $12 \mathrm{~m}$, and some emergent individuals (>15 m) are observed. In contrast, emergent individuals (> $25 \mathrm{~m}$ ) are frequently observed in the UFAs, the canopy is higher (10 to $20 \mathrm{~m}$ ) and it is possible to find a lower strata $(5$ to $8 \mathrm{~m}$ ). These structural canopy characteristics probably imposed by flooding, account in part for the differences in the cover index between the areas.

Branch and crown breakages were observed in some individuals during the study, mainly in the flooded area. Probably wind action, funneled along the stream channel, is responsible for the greater disturbance in the forest canopy of this area. The frequency of disturbances in the canopy contributed to the cover variation within and between areas and the greater this frequency (FA) the greater heterogeneity of the tree cover.

The seasonal variation in the canopy cover index of the sampled areas is related to the degree of deciduousness of these areas. The flooded area had greater deciduousness because it has a proportionally greater number of totally or partially deciduous species. When two phytosociological surveys carried out in Mata dos Godoy State Park are compared, one in the southern part of the Park on the Apertado stream edges (Soares-Silva et al., 1998) and the other in the northern part of the park (Soares-Silva \& Barroso, 1992), 11 and 7 species of the 25 species with greater IVI (importance value index) were deciduous or semi-deciduous in the first and second surveys, respectively. Furthermore, these species may have a higher density of individuals because they are tolerant to sporadic flooding, as is the case of Chrysophyllum gonocarpum (Bianchini, 1998) and Campomanesia xanthocarpa (Pimenta, 1998).

It is also possible that some species, which occur in both areas, may lose more leaves in FA than in 
UFA. This may be related to the plant water 'status' (Reich, 1995). Possibly, the FA has a drier atmosphere because it is more open, and consequently, there is a greater transpiration demand in the plants. Furthermore, the superficial part of the FA soil becomes dried out and compacted where the majority of the absorbent roots of the plants are found during the period of lower precipitation. If water take-up of the soil is not sufficient to compensate the transpiration stream, this may result in leaf abscission in some species, mainly those that do not have access to deeper water in the soil. Leaf abscission may also be related to alteration in hormone levels, as for example an increase in the abscisic acid level, because of reduced water take-up by the superficial roots.

The greater deciduousness in the flooded area may also be related to leaf production and maintenance cost (Kikuzawa, 1991). In a more lit environment and under unfavorable conditions, old leaves may abscise because of senescence (leaf life cycle) and be substituted by new leaves, more efficient at photosynthesis, when the environmental conditions become favorable again. The production cost of new leaves may be limiting in a more shaded environment, and the deciduousness may be limited to more lit individuals in the upper canopy and emergent individuals.

Sunlight declines exponentially as it crosses the canopy (Mulkey et al., 1996) and the light level which reaches the understorey is only $1 \%$ to $2 \%$ of the incident sunlight (Chazdon \& Fetcher, 1984). Small gaps and spaces in the foliage are crossed by light beams which enrich the understorey quantic energy (Martínez-Ramos, 1985) which may affect the performance of seedlings and young plants in these environments (Clark, 1990). The greater luminosity of the FA understorey may have favored the development of seedlings of some species to the detriment of others, which may have contributed to the structural differences observed among the studied areas. The differentiation of tree species in tropical dry forests may be highly dependent on the light-related environmental heterogeneity (Oliveira-Filho et al., 1998; Nicotra et al., 1999).

To sum up, the flooded area had greater variation in the cover index compared with unflooded areas because of the canopy characteristics, more frequent natural disturbances and the greater degree of deciduousness. All these causes seem to be related to the presence of the stream and flooding and their consequences. This may have important implications in the dynamic of the populations that occurs in these areas. Studies assessing the influence of light and flooding on populations present in both sampled areas would be essential to understand these communities.

\section{ACKNOWLEDGEMENTS}

We thank to PosGraduation Course Plant Biology, Universidade Estadual de Campinas. We thank to anonymous referees for their valuable comments on earlier version of the manuscript, too.

\section{RESUMO}

Este estudo foi desenvolvido no Parque Estadual Mata dos Godoy $\left(23^{\circ} 27^{\prime} \mathrm{S}, 51^{\circ} 15^{\prime} \mathrm{W}\right)$, região Sul do Brasil. O Parque apresenta grande heterogeneidade ambiental quando as partes norte (espigão) e sul (fundo de vale) são comparadas. A floresta é classificada como tropical semidecidual. As variações espaciais e temporais no grau de cobertura do dossel foram comparadas em sítios esporadicamente alagáveis e não alagáveis do Parque. Leituras foram realizadas sazonalmente, em parcelas de $100 \mathrm{~m}^{2}$, com um densiômetro esférico, da primavera de 1995 até o inverno de 1996. A área alagável apresentou maior variação espacial e temporal na cobertura do dossel do que as áreas não alagáveis, indicando ser mais aberta e mais iluminada. Esta maior heterogeneidade da área alagável pode ser devido às características estruturais do dossel (maior espaçamento entre indivíduos arbóreos, dossel mais baixo e menos estratificado), distúrbios naturais mais freqüentes e maior grau de deciduidade. Estas causas parecem estar relacionadas à presença do rio e ao alagamento e suas conseqüências.

\section{REFERENCES}

Bellingham, P. J.; Tanner, E. V. J.; Rich, P. M. and Goodland, T. C. R. (1996), Changes in light below the canopy of a Jamaican montane rainforest after a hurricane. J. Trop. Ecol., 12, 699-722 
Bianchini, E. (1998), Ecologia de população de Chrysophyllum gonocarpum (Mart. \& Eichler) Engl. no Parque Estadual Mata dos Godoy, Londrina, PR. Tese de doutoramento, Universidade de Campinas, Campinas, Brasil

Chazdon, R. L. and Fetcher, N. (1984), Photosynthetic light environments in a lowland tropical rain forest in Costa Rica. J. Ecol., 72, 553-564

Clark, D. B. (1990), The role of disturbance in the regeneration of neotropical moist forests. In Reproductive ecology of tropical forest plants, eds. K. S. Bawa \& M. Hadley. UNESCO / The Parthenon Publ., Paris, pp. 291-315

Denslow, J. S. (1980), Gap partitioning among tropical rain-forest trees. Biotropica, 12(suppl.), 47-55

Denslow, J. L. and Hartshorn, G. S. (1994), Tree-fall gap environments and forest dynamic processes. In La Selva: ecology and natural history of a neotropical rainforest, eds. L.A. McDade, K.S. Bawa, H.A. Hespenheide \& G.S. Hartshorn. The University of Chicago Press, Chicago, pp. 120-127

Gomez-Pompa, A. and Vázquez-Yanes, C. (1985), Estudios sobre la regeneracion de selvas en regiones calido-humedas de Mexico. In - Investigaciones sobre la regeneracion de selvas altas en Veracruz, Mexico, eds. A. Gomez-Pompa \& S. R. Amo. Editorial Alhambra Mexicana, Mexico, pp. 1-25

Hubbell, S. P. and Foster, R B. (1987), La estructura espacial en gran escala de un bosque neotropical. Rev. Biol. Trop. 35(supl. 1), 7-22

Joly, C. A. (1991), Flooding tolerance in tropical trees. In - Plant life under oxygen deprivation, eds. M.B. Jackson; D.D. Daves \& H. Lambers. SPB Academic Publishing, The Hague, pp. 23-34

Kikuzawa, K. (1991), A cost - benefit analysis of leaf habit and leaf longevity of trees and their geographical pattern. Amer. Nat., 138, 1250-1263

Lemmon, P. E. (1956), A spherical densiometer for estimating forest overstory density. For. Sci., 2, 314320

Lerdau, M. T.; Holbrook, N. M.; Mooney, H. A.; Rich, P. M. and Whitbeck, J. L. (1992), Seasonal patterns of acid fluctuations and resource storage in the arborescent Opuntia excelsa in relation to light availability and size. Oecologia, 92, 166-172

Lieberman, M.; Lieberman, D. and Peralta, R. (1989), Forests are not just Swiss cheese: canopy stereogeometry of non-gaps in tropical forests. Ecology, 70, 550-552

Martínez-Ramos, M. (1985), Claros, ciclos vitales de los arboles tropicales y regeneracion natural de las selvas altas perennifolias. In - Investigaciones sobre la regeneracion de selvas altas en Veracruz, Mexico, eds. A. Gomez-Pompa \& S. R. Amo. Editorial Alhambra Mexicana, Mexico, pp. 191-239
Martínez-Ramos, M.; Alvarez-Buylla, E. and Sarukhán, J. (1989), Tree demography and gap dynamics in a tropical rain forest. Ecology, 70, 555-558

Mori, S. A. and Becker, P. (1991), Flooding affects survival of Lecythidaceae in terra firme forest near Manaus, Brazil. Biotropica, 23, 87-90

Mulkey, S. S.; Kitajima, K. and Wright, S. J. (1996), Plant physiological ecology of tropical forest canopies. Tree, 11, 408-412

Nicotra, A.B., Chazdon, R.L. and Iriarte S.V.B. (1999), Spatial heterogeneity of light and woody seedling regeneration in tropical wet forests. Ecology, 80, 1908-1926

Oliveira-Filho, A. T.; Curi, N.; Vilela, E. A. and Carvalho, D. A. (1998), Effects of canopy gaps, topography, and soils on the distribution of woody species in a Central Brazilian Deciduous Dry Forest. Biotropica, 30, 362-375

Pimenta, J. A. (1998), Estudo populacional de Campomanesia xanthocarpa O.Berg (Myrtaceae) no Parque Estadual Mata dos Godoy, Londrina, PR. Tese de doutoramento, Universidade de Campinas, Campinas, Brasil

Reich, P. B. (1995), Phenology of tropical forests: patterns, causes, and consequences. Can. J. Bot., 73, 164-174

Richards, P. W. (1952), The tropical rain forest. Cambridge University Press, London

Silveira, M. (1993), Estrutura vegetacional em uma topossequência no Parque Estadual "Mata dos Godoy", Londrina, PR. Dissertação de mestrado, Universidade Federal do Paraná, Curitiba, Brasil

Smith, W. K.; Knapp, A. K. and Reiners, W. A. (1989), Penumbral effects on sunlight penetration in plant communities. Ecology, 70, 1603-1609

Spies, T. A. and Franklin, J. F. (1989), Gap characteristics and vegetation response in coniferous forests of the Pacific Northwest. Ecology, 70, 543546

Soares-Silva, L. H. and Barroso, G. M. (1992), Fitossociologia do estrato arbóreo da floresta na porção norte do Parque Estadual Mata dos Godoy, Londrina-PR, Brasil. In - Anais do VIII Congresso da Sociedade Botânica de São Paulo. Campinas, pp. 101-112

Soares-Silva, L. H.; Kita, K. K. and Silva, F. C. (1998), Fitossociologia de um trecho de floresta de galeria no Parque Estadual Mata dos Godoy, Londrina, PR, Brasil. Bol. Herb. Ezechias P. Heringer, 3, 46-62

Whitmore, T. C. (1989), Canopy gaps and the two major groups of forest trees. Ecology, 70, 1167-1178

Received: April 18, 2000;

Revised: May 31, 2000; Accepted: November 29, 2000. 